Egyptian J. of Nutrition Vol. XXXIV No. 2 (2019)

\title{
Effect of Low Fat Yoghurt Supplemented With Garden Cress Seeds Powder on Hypercholesterolemic Rats.
}

\author{
El sayed Hassan Atwaa', Ahdab A. Elmaadawy ${ }^{2}$ \\ 1- Food Science department, Faculty of Agriculture, Zagazig \\ University, Egypt \\ 2- Department of Home Economics, Faculty of Specific Education, \\ Zagazig University, Egypt
}

\begin{abstract}
Garden cress seeds powder has a rich composition of dietary fiber, minerals, antioxidant and vitamins. The study was carried out to evaluate the effect of fortification garden cress seeds powder on the physicochemical, rheological and sensory properties of low fat yoghurt ( $1 \%$ fat). Garden cress seeds powder was added at ratios of 1,2 and $3 \%$.

Manufacture yoghurt were analyzed for physicochemical, rheological and sensory properties. Results showed that gradual increase of $\mathrm{pH}$ values, dietary fiber, viscosity, phenolic content and antioxidant activity as garden cress seeds powder ratio was increased in low fat yoghurt. On the other hand, the acidity and synersis were decreased as the ratio of garden cress seeds powder was increased. Low fat yoghurt that containing of $3 \%$ of garden cress seeds powder
\end{abstract}




\section{El sayed Hassan Atwaa and Ahdab A. Elmaadawy}

were the highest of physicochemical properties, high acceptability sensory properties and improvement rheological properties (viscosity and syneresis), than the other treatments. Low fat yoghurt fortified with 3\% garden cress seeds were evaluated as a hypocholesterolemic agent in rats. garden cress seeds fortified yoghurt were able to lower the serum cholesterol, triacylglyceride (TG), low density lipoprotein cholesterol (LDL-C), and atherogenic index, but were found to increase the high density lipoprotein cholesterol (HDL-C) as compared to the corresponding high fat diet group (positive control). Also, results showed that garden cress seeds fortified yoghurt were able to improve the serum creatinine and blood urea as compared to the corresponding high fat diet.

Thus, the study demonstrates that garden cress seeds can be used as a source of phenolic compounds and dietary fiber in low fat yoghurt which enhanced its nutritional value, rheological and sensory properties and possess a hypolipidemic effect.

\section{Introduction}

Garden cress (Lepidiumsativum L.) is a fast growing annual herb that is native to Egypt and west of Asia, and presently it is cultivated in all over the world. In local languages, garden cress $(\mathrm{GC})$ is considered as an important medicinal crop in India (Tiwari et al., 2004). 
Egyptian J. of Nutrition Vol. XXXIV No. 2 (2019)

Garden cress seed (GCS) possesses several of pharmacological properties like antihyperglycemic properties (Behrouzian et al., 2014 and Hassan, et al., 2015). Antianemic, antioxidant, antibacterial and antifungal properties (Bansal, et al., 2012). galactogogues, nutritional and medicinal attributes, and are recommended for anti-diarrheal, cardiotonic, hypotensive, and has tremendous potential for the development of functional food by fortification with it. (Ait-yahia et al., 2018). Garden cress seed ( L. sativum) have contain protein , fat and dietary fiber. It is a good source of calcium, iron, magnesium and other nutrients (thiamine, , riboflavin, niacin) Gopalan et al., ( 2011).Also, garden cress seed oil (GCSO) has a balanced amount of polyunsaturated fatty acids (PUFA) (46.8\%) and monounsaturated fatty acids (MUFA) (37.6\%) (Jain and Grover, 2017).

Many studies showed that natural antioxidants, as flavanoids and other phenolic phytochemical present in plants are associated with reduced chronic disease risk and inhibit lipid peroxidation of human low-density lipoprotein in vitro (Goncalves et al., 2004).

Low fat dairy products including yoghurt have gained popularity because of consumer awareness about health concerns related to decreasing the risks connected with obesity and coronary heart diseases (Sandoval et al., 2004). However, the partial or total removal of fat from yoghurt decreases the overall quality perceived by the consumers (Folkenberg and 


\section{El sayed Hassan Atwaa and Ahdab A. Elmaadawy}

Martens, 2003). It was reported that reduction of fat content in yoghurt resulted in lower gel strength and firmness than full fat yoghurt, as a consequence of lower number of fat globules embedded in the protein network (Duboc and Mollet, 2003).To improve textural and functional properties of low fat yoghurt, the use of cereal fibers has been widely investigated (Hasania, 2017and Dabija et al., 2018).

The aim of this study to determine of physicochemical, antioxidant activity and total phenolic content of garden cress seeds and evaluation the effect of added garden cress seeds on physicochemical, rheological, and sensory properties of low fat yoghurt and to investigate the role of yoghurt fortified with garden cress seeds as hypocholesterolemic agents.

\section{Materials and Methods}

\section{Materials}

Fresh buffalo's milk (3\% fat) was obtained from Dairy Technology Unit, Food Science Department, Faculty of Agriculture, and Zigzag University, Egypt. Garden cress seeds were purchased from local market. The seeds were cleaned and rendered free of dust, dirt, foreign materials and broken seed. Preparation garden cress seed powder by the using of grinder seed is converted in to the powdered form. Sieving process with 40, 60 mesh sizes used to sieve the end product .

Cholesterol was obtained from pro- lap, France. Bile salts (gallbladder extract) were obtained from slaughtered cow. 
Egyptian J. of Nutrition Vol. XXXIV No. 2 (2019)

Adult males Wister albino rats $(100-120 \mathrm{gm}$.),was obtained from National Research Center.

Starter Cultures: Streptococcus salivarius subsp. thermophilus EMCC104 and Lactobacillus delbruekii subsp. bulgaricusEMCC1102. Were obtained from the Microbiological Resources Center (MIRCEN), Faculty of Agric. Aim Shams Univ., Egypt.

\section{Methods}

Determination of total phenolic content:

The concentration of total phenols was measured by a UV spectrophotometer (Jenway-UV-VIS Spectrophotometer), based on a colorimetric oxidation/ reduction reaction, as described by Skerget et al., (2005). The used oxidizing reagent was Folin-Ciocalteu reagent (AOAC, 1990).

\section{Radical scavenging activity (Scavenging DPPH):}

The electron donation ability of the obtained extracts was measured by bleaching of the purple colored solution of the 2, 2-diphenyl-1-picrylhydrazyl radical (DPPH) according to the method of Hanato et al., (1988) and modified method by (Gulcin et al., 2004). 


\section{El sayed Hassan Atwaa and Ahdab A. Elmaadawy}

\section{Manufacture of yoghurt:}

Fresh bulk buffalo's milk was separated to skim-milk and cream. Cream used to standardize the percentage of milk fat. Milk containing $3 \%$ fat was used in the preparation of yoghurt and served as a control (C). Low fat buffalo's milk (1\% fat) was divided into 4 portions. The first portion was left without additive as a control (C1), garden cress seeds powder was added to the other three portions at the rate of 1, 2 and 3\% (T1, T2 and, T3). The fortified milk bases were homogenized and heated to $90{ }^{\circ} \mathrm{C}$ for 15 min., then, cooled to $42 \pm 1{ }^{\circ} \mathrm{C}$, inoculated with $2 \%$ of yoghurt starter cultures, filled in plastic cups and incubated at $42{ }^{\circ} \mathrm{C}$ until a uniform coagulation was obtained. The yoghurt samples from all treatments were stored at $6 \pm 1{ }^{\circ} \mathrm{C}$ and analyzed at fresh time. This experiment was triplicated.

\section{Chemical analysis:}

Total solids, fat, total protein (TP) contents, titratable acidity and dietary fiber of yoghurt samples were determined according to $A O A C$, (2007). The changes in $\mathrm{pH}$ in the yoghurt samples during storage were measured using a laboratory $\mathrm{pH}$ meter with glass electrode (HANNA, Instrument, Portugal). Carbohydrate, crude fiber ,ash , calcium, phosphorus, manganese, potassium and sodium contents were determined according to AOAC, (2007). while iron and zinc content were determined according to Page et al., (1992). 
Egyptian J. of Nutrition Vol. XXXIV No. 2 (2019)

\section{Rheological measurements:}

The viscosity and released whey from yoghurt samples was measured according to the method of Aryana, (2003). The quantity of whey collected from every sample in graduated cylinder after $2 \mathrm{~h}$ of drainage at $20{ }^{\circ} \mathrm{C}$ was used as index of syneresis. Viscosity of nonfat yoghurt samples was determined using Rotational Viscometer Type Lab. Line Model 5437. Results exressed as CPS.

\section{Sensory evaluation:}

The sensory properties of yoghurt samples were assessed by 10 panel members of the Dairy Sci., Dep., Fac. Agric., Zagazig, Univ. for flavour (60) body and texture (30) and appearance (10) as reported according to Nelson and Trout, (1981).

\section{Preparation of standard and high-fat diets:}

Basal diet: the basal diets was prepared according to the following formula as mentioned by (AIN, 1993) as follow: protein $(10 \%)$, corn oil $(10 \%)$, vitamin mixture $(1 \%)$, mineral mixture $(4 \%)$, choline chloride $(0.2 \%)$, methionine $(0.3 \%)$, cellulose $(5 \%)$, and the remained is corn starch $(69.5 \%)$. The used vitamin mixture component was that recommended by (Campbell, 1963) while the salt mixture used was formulated according to (Hegsted, 1941)..

High- cholesterol diet: the basal pellet diets which described above was grinded and supplemented with ; $5 \%$ buffalo fat , $1 \%$ 


\section{El sayed Hassan Atwaa and Ahdab A. Elmaadawy}

cholesterol and $0.25 \%$ bile s acid according to Sharma, (1984) and Pandya et al.,(2006).

Condition and preparation of the animals:

Twenty four healthy adult male Wister albino rats $(140 \pm 10 \mathrm{~g})$ were divided into four groups of six rats each. After the adaptation period (7 days), one group continued feeding on the basal diet and served as negative control (Group1).Another group was fed on high fat diet and served as a positive control (Group 2). The two other groups were allowed to feed on hypercholesterolemic diet with $20 \%$ low fat yoghurt without any additives (Group 3) and 20\% low fat yoghurt fortified with 3\% garden cress seeds powder (Group 4) for 30 days. At the end of experimentation period (i.e., day 30), blood samples were collected from all animals from retro-orbital venous plexus for biochemical analyses.

\section{Biochemical assays for lipids:}

Cholesterol, HDL- cholesterol and triacylglyceride levels were estimated from serum by CHOD-PAP method and GPOPAP method (Devi \& Sharma, 2004), respectively. LDLcholesterol was calculated following the method by Johnson et al., (1997). While the atherogenic index was calculated by using the method described by Muruganandan et al., (2005). Total serum protein, serum albumin and serum globulins were determined according to Henry, (1964),Doumas et al. ,(1971) and Renhold, (1953), respectively. Kidney function was 
Egyptian J. of Nutrition Vol. XXXIV No. 2 (2019)

determined as serum creatinine and blood urea nitrogen according to Reder and Hartmann, (1994).

\section{Statistical analysis:}

The obtained results were evaluated statistically using analysis of variance as reported by McClave\& Benson, (1991). In addition the other reported values were expressed as mean $\pm S D$ and \pm SE, two - tailed Student's $t$ test was used to compare between different groups. . P value less than 0.05 was considered statistically significant. SPSS (Chicago, IL, USA) software window Version 16 was used.

\section{Results and Discussion}

Chemical composition, minerals content and antioxidant properties of garden cress seeds.

The proximate macro nutrients contents of garden cress seeds powder are illustrated in Table (1). Protein, fat, ash, crude fiber and carbohydrate contents of garden cress seeds powder were $(18.92,14.20,4.60,17.84$ and $44.44 \mathrm{~g} / 100 \mathrm{~g}$ respectively. These results are in agreement with the data obtained by Zia-UI-Haq et al.,(2012) and Doke\&Guha ,(2014).

Minerals content of garden cress seeds are presented in Table (1). The results showed that $\mathrm{Ca}, \mathrm{Zn}, \mathrm{Fe}, \mathrm{Mg}, \mathrm{K}, \mathrm{P}$, and $\mathrm{Na}$ contents of garden cress seeds powder were (220.212, $4.246,5.628,342.20,2650.50,246.30$. and $980.320 \mathrm{mg} / 100 \mathrm{~g}$ ) respectively. The highest content was potassium, while the 


\section{El sayed Hassan Atwaa and Ahdab A. Elmaadawy}

lowest content was $\mathrm{Zn}$. These results are in agreement with the data obtained by Zia-UI-Haq et al., (2012),Doke\&Guha ,(2014) and Chaudhary\& Gupta, (2017).

Total phenolic content TPC of ethanolic GCS was 1382.6 - $1584.2 \mathrm{mg} / 100 \mathrm{~g}$. Total flavonoid content TFC of ethanolic GCSE was $680.12-820.6 \mathrm{mg} / 100 \mathrm{~g}$, while the radical scavenging activity RSA (\%) of ethanolic GCS was $90.4 \%$. These results agree with that previously reported (Zia-UI-Haq et al., 2012 and Ait-yahia et al., 2018) who studied antioxidant activity of garden cress seeds extract. Therefore, GCSE could be a good source of bioactive compounds with high antioxidant potential.

Chemical composition of low fat yoghurt fortified with garden cress seeds powder:

Tables (2) showed that yoghurt made from milk containing 3\% fat (C) had the highest total solids (TS) and it was significantly $(p=0.05)$ different from all yoghurt treatments, while the low fat yoghurt treatments exhibited the least (TS) content. This decrease in TS was due to the fat separation from milk yoghurt treatments. The TS content of low fat yoghurt fortified with GCS increased gradually by increasing the percentage added.

Lowering fat content in low fat yoghurt milks slightly increased the total protein in low fat yoghurt about the full fat yoghurt (C). The total protein of low fat yoghurt fortified with GCS slightly increased by increasing the percentage added 
Egyptian J. of Nutrition Vol. XXXIV No. 2 (2019)

Control yoghurt (C) contained highest fat content was significantly $(P=0.05)$ different from other treatments. On the other hand, fortification of low fat milk with GCS did not affect the fat content of the resultant yoghurt.

Dietary fiber content increased by adding of garden cress seeds powder in the yogurt samples. Dietary fiber contents were $0.72,1.28$ and $2.12 \mathrm{~g}$ dietary fiber $/ 100 \mathrm{~g}$ in yogurt prepared with 1, 2 and $3 \%$ garden cress seeds powder respectively. The dietary fibers may offer physiological effects on viscosity, solubility, oil-binding capacity, hydration property and antioxidant activity in food products. Jambi, (2018), used date pits powder as source of dietary fiber for improving rheological properties of yogurt.

Slight differences were observed in acidity of yoghurt from different treatments. Reduced fat slightly increased acidity but fortification of yoghurt milk with GCS at different concentration was decreased acidity of low fat yoghurt as the ratio of garden cress seeds powder was increased.

Changes in $\mathrm{pH}$ value of yoghurt from different treatments as affected by fortification of GCS followed almost opposite trend to acidity. These results are in agreement with those reported by Hasani et al., (2017), who studied the effect of different amounts of barley bran on the physicochemical properties of low-fat yoghurt. Also, Al-hamdani et al., (2015),found that supplemented yogurt with 2 and $4 \%$ of 


\section{El sayed Hassan Atwaa and Ahdab A. Elmaadawy}

lupine flour were the highest positive effect on
physicochemical properties.

Total phenolic content and radical scavenging activity of yogurt prepared with different ratio of garden cress seeds powder.

Total phenolic content and radical scavenging activity of yogurt prepared with different ratio of garden cress seeds powder are illustrated in Table (3): Total phenolic content of yogurt prepared with garden cress seeds powder were increased by garden cress seeds powder increasing in the yogurt product. Radical scavenging activity of yogurt prepared with garden cress seeds powder were increased by garden cress seeds powder increasing in the yogurt product. These results are in agreement with those reported by Jambi, (2018) who found that total phenolic content and radical scavenging activity of yogurt prepared with date pits powder were increasing date pits powder ratios increased in the yogurt product.

Rheological properties of low fat yoghurt fortified with garden cress seeds powder:

Separation of whey increased by decreasing the fat content in yoghurt but fortification of yoghurt with GCS significantly reduced whey syneresis compared with low fat yoghurt without additives $(\mathrm{C} 1)$ and this reduction was proportional to the fortification ratio Table (4). These results might be due to increasing the water holding capacity brought 
Egyptian J. of Nutrition Vol. XXXIV No. 2 (2019)

by GCS in the resultant curd. A similar observation was found by Behnia et al., (2013) in fresh yoghurt containing cress seed gum.

Non fortified low fat yoghurt were significantly less viscous than full fat yoghurt (control) but fortification of yoghurt milk with GCS significantly increased $(P=0.05)$ the viscosity of the resultant yoghurt. The increase was slightly proportional to the rate of additives. This increase could be attributed to the water hydration of GCS. Similar results were reported by Hassan et al., (2015), who found that addition of cress seed mucilage or guar gum to yoghurt reduced its whey syneresis and increased viscosity than control yoghurt.

\section{Organoleptic properties of low fat yoghurt fortified with garden cress seeds powder:}

Scores of organoleptic properties flavour, body \& texture, appearance, acidity and total scores) of low fat yoghurt without additives or with added GCS are shown in Table (5).

It is evident from these results that, the reduction of milk fat in (C1) gained lowest scores for organoleptic properties. Fortification of low fat milk with GCS improved the organoleptic properties of low fat treatments and this improvement was proportional to the fortification ratio, low fat fortified with GCS 3 $\%$ was similar to the full fat yoghurt (control) . 


\section{El sayed Hassan Atwaa and Ahdab A. Elmaadawy}

A similar observation was found by Al-hamdani et al., (2015), who found that sensory evaluation of the supplemented yogurt product were showed that the 2 and $4 \%$ of lupine flour for both origin were the highest positive effect on physicochemical and sensory scores (flavor, taste, acidity, texture and consistency, appearance, and the total properties)

\section{Biochemical assays for lipids}

There was a significant increase in the levels of serum cholesterol, triacylglyceride and LDL-C and a decrease in level of HDL-C in the high fat diet fed animals when compared to normal fed rats. Elevated level of blood cholesterol especially LDL-C is a known major risk factor for chronic heart diseases (CHD) whereas HDL-C is cardio protective.

Treatment with low fat yoghurt fortified with garden cress seeds, significantly decreased the levels of total cholesterol and LDL-C as compare to the controls (Table 6), this may be due to a high content of dietary fiber and phenolic compounds of garden cress seeds which have an antihyperglycemic properties (Behrouzian et al., 2014 and Hassan et al., 2015).

Similar results were reported by Alharbi and Sobhy, (2017) who found that feeding rats on GCS powder caused a decrease of serum levels of cholesterol, and serum triglyceride. Atherogenic index indicates the deposition of foam cells or plaque or fatty infiltration or lipids in heart, coronaries, aorta, 
Egyptian J. of Nutrition Vol. XXXIV No. 2 (2019)

liver and kidneys. The higher the atherogenic index, the higher is the risk of the above organs for oxidative damage (Mehta et al., 2003).Atherogenic index was significantly reduced in the low fat yoghurt fortified with garden cress seeds, treated groups Alharbi and Sobhy,(2017) .High fat diet (HFD) causes the oxidative stress which finally increases production of reactive oxygen species. Since the result of the study indicated that the GCS has beneficial effect on lipid profile.

Hypocholesterolemic state was accompanied by a high significant decrease in total serum protein, albumin and globulin for positive control the lowest levels of serum total protein, and albumin in control positive may be caused by the disorder in liver. Serum total protein, albumin and globulin were increased for the group treated with low fat yoghurt fortified with garden cress seeds. (Table 7), this finding can explain the possible effect of garden cress seeds consumption on improving liver function for rats suffering for hepatotoxicity. Similar results were reported by Abulnaja and El Rabey,(2015) who found that feeding of rats on barley bran improving liver function and increased of serum levels protein, albumin and globulin than hypercholesterolemic diet or positive control rats.

As shown in Table 7, hypercholesterolemia rats fed on $20 \%$ yoghurt fortified with $3 \%$ garden cress seeds decreased urea and creatininelevels comparedto group (G2) hypercholesterolemia rats and fed on basal diet after 30 days. The levels of creatinine and uric acid have been reported as a 


\section{El sayed Hassan Atwaa and Ahdab A. Elmaadawy}

factor finding in lead toxicity. The mechanism through which lead exposure raises the level of uric acid is unclear but is thought to be due to damaged renal tubules by lead (Ghalehkand et al., 2012).GCS components have demonstrated chronic disease fighting activity, particularly for protection against cardiovascular disease and certain cancers (Behrouzian et al., 2014).A similar observation was found by Althnaian,(2014), found that feeding of rats on dietary supplementation of garden cress seed decrease of urea and creatinine levels than rats fed high cholesterol diet or positive control.

\section{Conclusion}

Garden cress seeds (GCS) showed strong antioxidant capacity and high content of dietary fiber. Therefore, garden cress seeds could be used as natural additives in manufacture of low fat yoghurt to improve its physicochemical, rheological and sensory properties. Also, the observed cholesterol reducing action of the GCS indicates the hypolipidemic activity. 
Egyptian J. of Nutrition Vol. XXXIV No. 2 (2019)

Table (1): Chemical composition, minerals content and antioxidant properties of garden cress seeds.

\begin{tabular}{c|c}
\hline \multicolumn{2}{c}{ Chemical composition $(\mathrm{g} / 100 \mathrm{~g})$} \\
\hline Crude protein & 18.92 \\
\hline Crude Fat & 14.20 \\
\hline Ash & 4.60 \\
\hline Crude Fiber & 17.84 \\
\hline Carbohydrate & 44.44 \\
\hline Minerals content $(\mathrm{mg} / 100 \mathrm{~g})$ \\
\hline $\mathrm{Ca}$ & 220.212 \\
\hline $\mathrm{Zn}$ & 4.246 \\
\hline $\mathrm{Fe}$ & 5.628 \\
\hline $\mathrm{K}$ & 342.20 \\
\hline $\mathrm{Na}$ & 2650.50 \\
\hline $\mathrm{P}$ & 246.30 \\
\hline \multicolumn{2}{c}{ Antioxidant properties } \\
\hline Total phenolic compounds (mg/100g) & 980.320 \\
\hline Total flavonoids compounds(mg/100g) & $1382.6-1584.2$ \\
\hline Radical scavenging activity (RSA) \% & $680.12-820.6$ \\
\hline
\end{tabular}




\section{El sayed Hassan Atwaa and Ahdab A. Elmaadawy}

Table (2): Chemical analysis of low fat yoghurt as affected by adding garden cress seeds powder.

\begin{tabular}{c|c|c|c|c|c|c}
\hline $\begin{array}{c}\text { Treatme } \\
\text { nt }\end{array}$ & $\begin{array}{c}\text { Total } \\
\text { solids\% }\end{array}$ & $\begin{array}{c}\text { Total } \\
\text { fat\% }\end{array}$ & $\begin{array}{c}\text { Total } \\
\text { protein\% }\end{array}$ & Fiber \% & Acidity & $\mathrm{pH}$ \\
\hline $\mathrm{C}$ & 11.80 & 3.16 & 3.58 & 0.0 & 0.85 & 4.56 \\
& $\pm 0.47 \mathrm{~A}$ & $\pm 0.15 \mathrm{~A}$ & $\pm 0.65 \mathrm{~B}$ & $\pm 0.02 \mathrm{D}$ & $\pm 0.08 \mathrm{E}$ & $\pm 1.05 \mathrm{~A}$ \\
\hline $\mathrm{C} 1$ & 10.12 & 1.22 & 3.84 & 0.0 & 0.96 & 4.20 \\
& $\pm 0.45 \mathrm{D}$ & $\pm 0.12 \mathrm{BC}$ & $\pm 0.68 \mathrm{~B}$ & $\pm 0.01 \mathrm{D}$ & $\pm 0.11 \mathrm{~A}$ & $\pm 1.0 \mathrm{D}$ \\
\hline $\mathrm{T} 1$ & 10.24 & $1.30 \pm 0.14$ & 4.14 & 0.72 & 0.94 & 4.26 \\
& $\pm 0.42 \mathrm{D}$ & $\mathrm{BC}$ & $\pm 0.75 \mathrm{AB}$ & $\pm 0.05 \mathrm{C}$ & $\pm 0.09 \mathrm{~B}$ & $\pm 1.03 \mathrm{C}$ \\
\hline $\mathrm{T} 2$ & 10.78 & 1.38 & 4.26 & 1.28 & 0.92 & 4.28 \\
& $\pm 0.38 \mathrm{C}$ & $\pm 0.10 \mathrm{~B}$ & $\pm 0.77 \mathrm{AB}$ & $\pm 0.09 \mathrm{~B}$ & $\pm 0.08 \mathrm{C}$ & $\pm 1.05 \mathrm{C}$ \\
\hline \multirow{2}{*}{$\mathrm{T} 3$} & 11.02 & 1.44 & 4.38 & 2.12 & 0.90 & 4.34 \\
& $\pm 0.45 \mathrm{~B}$ & $\pm 0.12 \mathrm{~B}$ & $\pm 0.75 \mathrm{~A}$ & $\pm 0.11 \mathrm{~A}$ & $\pm 0.07 \mathrm{D}$ & $\pm 1.02 \mathrm{~B}$ \\
\hline
\end{tabular}

Values with different letters in the same column or row are significantly different $(\mathrm{P}<$ 0.05)

C: control yoghurt

C 1: Low fat yoghurt (1\% fat).

T2: Low fat yoghurt treated with $1 \%$ garden cress seeds powder

T2: Low fat yoghurt treated with $2 \%$ garden cress seeds powder

T2: Low fat yoghurt treated with $3 \%$ garden cress seeds powder 
Egyptian J. of Nutrition Vol. XXXIV No. 2 (2019)

Table (3): The effect of different ratio of garden cress seeds powder on total phenolic content and radical scavenging activity of yogurt.

\begin{tabular}{c|c|c}
\hline Treatment & $\begin{array}{c}\text { Total phenolic content } \\
(\mathrm{mg} / 100 \mathrm{~g})\end{array}$ & $\begin{array}{c}\text { Radical scavenging activity } \\
\mathrm{RSA} \%\end{array}$ \\
\hline $\mathrm{C}$ & $84.60 \pm 3.12 \mathrm{D}$ & $44.80 \pm 1.45 \mathrm{D}$ \\
\hline $\mathrm{C} 1$ & $82.42 \pm 3.05 \mathrm{D}$ & $42.36 \pm 1.32 \mathrm{D}$ \\
\hline T1 & $102.20 \pm 4.20 \mathrm{C}$ & $52.14 \pm 1.58 \mathrm{C}$ \\
\hline T2 & $250.64 \pm 5.60 \mathrm{~B}$ & $64.20 \pm 1.94 \mathrm{~B}$ \\
\hline T3 & $310.14 \pm 12.14 \mathrm{~A}$ & $78.32 \pm 2.05 \mathrm{~A}$ \\
\hline
\end{tabular}

$\overline{\text { Values with different letters in the same column or row are significantly different }(\mathrm{P}}<$ 0.05)

Table (4): Rheological properties of low fat yoghurt as affected by adding garden cress seeds powder.

\begin{tabular}{c|c|c}
\hline Treatment & Whey syneresis $(\mathrm{ml} / 100 \mathrm{gm})$ & Viscosity (C. P.S.) \\
\hline C & $27 \pm 0.46 \mathrm{E}$ & $5200 \pm 0112 \mathrm{~A}$ \\
\hline C1 & $38 \pm 0.52 \mathrm{~A}$ & $4200 \pm 110 \mathrm{E}$ \\
\hline T1 & $35 \pm 0.50 \mathrm{~B}$ & $4500 \pm 208 \mathrm{D}$ \\
\hline T2 & $32 \pm 0.48 \mathrm{C}$ & $4800 \pm 214 \mathrm{C}$ \\
\hline T3 & $30 \pm 0.53 \mathrm{D}$ & $5000 \pm 304 \mathrm{~B}$ \\
\hline
\end{tabular}

Values with different letters in the same column or row are significantly different $(\mathrm{P}<$ 0.05) 


\section{El sayed Hassan Atwaa and Ahdab A. Elmaadawy}

Table (5): Organoleptic properties of low fat yoghurt as affected by adding garden cress seeds powder.

\begin{tabular}{c|c|c|c|c}
\hline Treatments & $\begin{array}{c}\text { Appearance } \\
(10)\end{array}$ & Flavour (60) & $\begin{array}{c}\text { Body\& } \\
\text { texture (30) }\end{array}$ & Total (100) \\
\hline C & $10 \pm 0.25 \mathrm{~A}$ & $58 \pm 0.42 \mathrm{~A}$ & $30 \pm 0.36 \mathrm{~A}$ & $98 \pm 0.92 \mathrm{~A}$ \\
\hline $\mathrm{C} 1$ & $8 \pm 0.22 \mathrm{~B}$ & $52 \pm 0.38 \mathrm{D}$ & $23 \pm 0.28 \mathrm{E}$ & $83 \pm 0.78 \mathrm{E}$ \\
\hline T1 & $8 \pm 0.20 \mathrm{~B}$ & $54 \pm 0.35 \mathrm{C}$ & $25 \pm 0.30 \mathrm{D}$ & $87 \pm 0.82 \mathrm{D}$ \\
\hline T2 & $7 \pm 0.18 \mathrm{C}$ & $54 \pm 0.37 \mathrm{C}$ & $27 \pm 0.34 \mathrm{C}$ & $88 \pm 0.84 \mathrm{C}$ \\
\hline T3 & $6 \pm 0.15 \mathrm{D}$ & $56 \pm 0.35 \mathrm{~B}$ & $29 \pm 0.34 \mathrm{~B}$ & $91 \pm 0.90 \mathrm{~B}$ \\
\hline
\end{tabular}

Values with different letters in the same column or row are significantly different $(\mathrm{P}<$ $0.05)$

Table 6. Effect of low fat yoghurt fortified with garden cress seeds powder on lipid profile in cholesterol fed hyperlipidemia rats.

\begin{tabular}{c|c|c|c|c|c}
\hline Groups & $\begin{array}{c}\text { Cholesterol } \\
(\mathrm{mg} / \mathrm{dl})\end{array}$ & $\begin{array}{c}\text { Triacylglyce } \\
\text { ride } \\
(\mathrm{mg} / \mathrm{dl})\end{array}$ & $\begin{array}{c}\text { LDL-C } \\
(\mathrm{mg} / \mathrm{dl})\end{array}$ & $\begin{array}{c}\text { HDL-C } \\
(\mathrm{mg} / \mathrm{dl})\end{array}$ & $\begin{array}{c}\text { Atherogenic } \\
\text { index }\end{array}$ \\
\hline Group(1) & 96.20 & 142.72 & 29.00 & 52.70 & 1.14 \\
$\pm 6.35 \mathrm{C}$ & $\pm 3.62 \mathrm{C}$ & $\pm 0.24 \mathrm{C}$ & $\pm 4.28 \mathrm{~B}$ & $\pm 0.25 \mathrm{C}$ \\
\hline Group(2) & 178.24 & 292.60 & 68.20 & 34.22 & 5.20 \\
& $\pm 8.54 \mathrm{~A}$ & $\pm 6.18 \mathrm{~A}$ & $\pm 0.58 \mathrm{~A}$ & $\pm 2.36 \mathrm{D}$ & $\pm 1.50 \mathrm{~A}$ \\
\hline Group(3) & 126.30 & 218.24 & 42.34 & 42.12 & 3.40 \\
& $\pm 7.46 \mathrm{~B}$ & $\pm 5.95 \mathrm{~B}$ & $\pm 0.52 \mathrm{~B}$ & $\pm 3.40 \mathrm{C}$ & $\pm 0.68 \mathrm{~B}$ \\
\hline Group(4) & 84.36 & 114.62 & 17.60 & 64.30 & 1.04 \\
& $\pm 6.14 \mathrm{D}$ & $\pm 3.24 \mathrm{D}$ & $\pm 0.20 \mathrm{D}$ & $\pm 4.52 \mathrm{~A}$ & $\pm 0.21 \mathrm{CD}$ \\
\hline
\end{tabular}

Values with different letters in the same column or row are significantly different $(\mathrm{P}<$ $0.05)$

Group (1) -Control diet or negative control

Group (2) - hypercholesterolemic diet or positive control

Group (3) - hypercholesterolemic diet+20\% low fat yoghurt.

Group (4) - hypercholesterolemic diet $+20 \%$ low fat yoghurt fortified with $3 \%$ garden cress seeds powder. 
Egyptian J. of Nutrition Vol. XXXIV No. 2 (2019)

Table (7). Effect of low fat yoghurt fortified with garden cress seeds powder on serum total protein, albumin, globulin $(\mathrm{mg} / \mathrm{dl})$, creatinine, urea contents of male rats.

\begin{tabular}{l|c|c|c|c|c}
\hline Groups & $\begin{array}{c}\text { Total } \\
\text { protein } \\
(\mathrm{mg} / \mathrm{dl})\end{array}$ & $\begin{array}{c}\text { Albumin } \\
(\mathrm{mg} / \mathrm{dl})\end{array}$ & $\begin{array}{c}\text { Globulin } \\
(\mathrm{mg} / \mathrm{dl})\end{array}$ & $\begin{array}{c}\text { Creatinine } \\
(\mathrm{mg} / \mathrm{dl})\end{array}$ & $\begin{array}{c}\text { Urea } \\
(\mathrm{mg} / \mathrm{dl})\end{array}$ \\
\hline Group(1) & $8.96 \pm 0.62 \mathrm{~A}$ & $6.20 \pm 0.24 \mathrm{~A}$ & $2.76 \pm 0.14 \mathrm{C}$ & $0.942 \pm 0.05 \mathrm{C}$ & $40.12 \pm 1.15 \mathrm{C}$ \\
\hline Group(2) & $6.78 \pm 0.75 \mathrm{D}$ & $4.20 \pm 0.30 \mathrm{D}$ & $2.58 \pm 0.26 \mathrm{~A}$ & $1.374 \pm 1.04 \mathrm{~A}$ & $48.21 \pm 1.32 \mathrm{~A}$ \\
\hline Group(3) & $7.14 \pm 0.68 \mathrm{C}$ & $4.90 \pm 0.28 \mathrm{C}$ & $2.24 \pm 0.24 \mathrm{~B}$ & $1.246 \pm 1.02 \mathrm{~B}$ & $42.36 \pm 2.24 \mathrm{~B}$ \\
\hline Group(4) & $8.16 \pm 0.60 \mathrm{~B}$ & $5.60 \pm 0.22 \mathrm{~B}$ & $2.56 \pm 0.12 \mathrm{D}$ & $0.865 \pm 0.04 \mathrm{D}$ & $38.43 \pm 1.06 \mathrm{D}$ \\
\hline
\end{tabular}

Values with different letters in the same column or row are significantly different $(\mathrm{P}<$ 0.05)

Group (1) -Control diet or negative control

Group (2) - hypercholesterolemic diet or positive control

Group (3) - hypercholesterolemic diet+20\% low fat yoghurt.

Group (4) - hypercholesterolemic diet $+20 \%$ low fat yoghurt fortified with $3 \%$ garden cress seeds powder 
El sayed Hassan Atwaa and Ahdab A. Elmaadawy

\section{References}

Abulnaja ,K.O., and El Rabey, H.A.(2015).

The Efficiency of Barley (Hordeumvulgare) Bran in Ameliorating Blood and Treating Fatty Heart and Liver of Male Rats. Evid Based Complement Alternat Med., 2015: 740716.

Ain, (1993).

American Institute of Nutrition Purified Diet for Laboratory Rodent, Final Report. Journal of Nutrition, 123: 1939 - 1951.

Ait-yahia, O., Perreau, F., Bouzroura, S., Benmalek, Y., Dob, T., and Belkebir, T. (2018).

Chemical composition and biological activities of nbutanol extract of Lepidiumsativum L (Brassicaceae) seed. Tropical Journal of Pharmaceutical Research; 17 (5): 891-896.

Al-hamdani, .M.S., Al-Anbary , E.H., and Ahmed, .M.(2015).

Effect of Lupin (Lupinusalbifrons) flour on microbial and sensory properties of local Yoghurt.Advances in Life Science and Technology, 34.1-6. 
Egyptian J. of Nutrition Vol. XXXIV No. 2 (2019)

Alharbi, F.K., and Sobhy, H.M. (2017).

Influence of dietary supplementation of Garden cress (Lepidiumsativum L.) on histopathology and serum biochemistry in Diabetic Rats. Egypt. J. Chem. Environ. Health, 3 (1):1-19.

\section{Althnaian, T. (2014).}

Influence of dietary supplementation of Garden cress (Lepidiumsativum L.) on liver histopathology and serum biochemistry in rats fed high cholesterol diet. J. Adv. Vet. Anim. Res., 1(4): 216-223.

AOAC. (2007).

Association of official analytical chemists - official method of analysis.(18th Ed.), Benjamin Franklin Station Washington, D.C., USA.

AOAC. (1990).

Association of official analytical chemists - Official methods of analysis of the AOAC, 15th ed. Methods 932.06, 925.09, 985.29, 923.03.. Arlington, VA, USA.

\section{Aryana, K.J. (2003).}

Folic acid fortified fat free plain set yoghurts. Int. J. Dairy Technol., 56(4) : 219-222. 


\section{El sayed Hassan Atwaa and Ahdab A. Elmaadawy}

Bansal, D., Bhasin, P., Yadav, O., and Punia, A. (2012). Assessment of genetic diversity in Lepidiumsativum(Chandrasur) a medicinal herb used in folklore remedies in India using RAPD," Journal of Genetic Engineering and Biotechnology, 10 ( 1) ; 39-45.

Behnia, A., Karazhiyan, H., Niazmand, R., Nafchi, A.R.M., (2013).

Rheological properties of low fat yogurt containing cress seed gum. Agric. Sci. 4, 29-32.

Behrouzian, F., Razavi, S. M. A., and Phillips, G. O. (2014).

Cress seed (Lepidiumsativum) mucilage, an overview," Bioactive Carbohydrates and Dietary Fibre, vol. 3, no. 1, pp. 17-28, 2014.

Campbell, J. A. (1963).

Methodology of Protein Evaluation.RGA Nutr.Document R. Led.37 .June meeting, New York.

Chaudhary, B., and Gupta, R. (2017).

Nutritional evaluation of garden cress seeds (Lepidiumsativum).International Journal Food and Nutritional science. 6, 3,:35-40. 
Egyptian J. of Nutrition Vol. XXXIV No. 2 (2019)

Dabija, A., Codinăa, G.G., Gâtlana, A.M., and Rusu, L. (2018).

Quality assessment of yogurt enriched with different types of fibers. Cyta - Journal of Food. 16, 1, 859-867.

Devi, R.K., and Sharma, D.K. (2004).

Hypolipidemic effect of different extracts of ClerodendroncolebrookianumWalp in normal and highfat diet fed rats. J Ethnopharmacol 90:63-68.

Doke, S., and Guha, M. (2014).

Garden cress (Lepidiumsativum L.) seeds an important medicinal source. J. Nat. Prod. Plant Resour., 4(1):6980.

Doumas, B. T., Watson, W. A., and Biggs, H. G. (1971).

Albuminstandards and the measurement of serum albumin with bromocresol green. Clin.Chem.Acta, 31: 87-96.

Duboc, P., and Mollet, B. (2003).

Applications of exopolysaccharides in the dairy industry. Int. Dairy. J., 11, 759-768, 


\section{El sayed Hassan Atwaa and Ahdab A. Elmaadawy}

Folkenberg, D.M., and Martens, M. (2003).

Sensory properties of low fat yogurts. Part A: Effect of fat content, fermentation culture and addition of non-fat dry milk on the sensory properties of plain yogurts. Milchwissenschaft, 58, 48-51.

Ghalehkandi, J.G., Ebrahimnezhad, Y., and Nobar, R.S. (2012).

Effect of Garlic ( Alliumsativum) Aqueous Extract on serum values of Urea, Uric-Acid and Creatinine compared with Chromium Chloride in Male Rats. Annals of Biological Research, 3 (9):4485-4490.

Goncalves, B., Landbo, A., Let, M., Silva, A., Rosa, E., and Meyer, A. (2004).

Storage affects the phenolic profiles and antioxidant activities of cherries on human low-density lipoprotein. J. Sci. Food Agric., 84, 1013 - 1120.

Gopalan, C., Sastri, B. V. R., Balasubramanian, S. C., Rao, B. S. N., Deosthale, Y. G., and Pant, K. C. (2011). Nutritive value of Indian foods. National Institute of Nutrition. Hyderabad, India: Indian Council of Medical Research. 
Egyptian J. of Nutrition Vol. XXXIV No. 2 (2019)

Gulcin, I., Kufrevioglu, O.I., Oktay, M., and Buyukokuroglu, M.E. (2004).

Antioxidant, antimicrobial, antiulcer and analgesic activities of nettle (Urticadioica L.). J. Ethnopharmacology, 90: 205-215.

Hanato, T., Kagawa, H., Yasuhara, T., and Okuda, T. (1988). Two new flavonoids and other constituents in licorice root: their relative astringency and radical scavenging effects. Chem. Pharm. Bull., 36: 2090-2097.

Hasani, S., Sari, A.A., Heshmati, A., and Karami, M. (2017). Physicochemical and sensory attributes assessment of functional low-fat yogurt produced by incorporation of barley bran and Lactobacillus acidophilus .Food Sci. Nutr. , 5:875-880.

Hassan, L. K., Haggag, H., ElKalyoubi, M., Abd EL-Aziz, M., El-Sayed, M., and Sayed, A.(2015).

Physico-chemical properties of yoghurt containing cress seed mucilage or guar gum," Annals of Agricultural Sciences, 60, (1); 21-28.

Hegsted, D.; Mills, R. and Perkins, E. (1941):

Salt mixture. J. Biol. Chem., 138: 459. 


\section{El sayed Hassan Atwaa and Ahdab A. Elmaadawy}

Henry, R.J. (1964).

Clinical Chemistry, Harber and Row Publisher, New York, 181.

Jain, T., and Grover, K. (2017).

Nutritional Evaluation of Garden Cress Chikki.Agri.Res\&.Tech.Open.Access.J. 4 (2): 555-631 .

Jambi, H.A. (2018).

Evaluation of Physio-Chemical and Sensory Properties of Yogurt Prepared with Date Pits Powder. Current Science International,7 (1) :1-9.

Johnson, R., McNutt, P., MacMahon, S., and Robson, R. (1997).

Use of the friedewald formula to estimate LDLcholesterol in patients with chronic renal failure on dialysis. Clin.Chem., 43: 2183-2184.

McClave, J.T., and Benson, P. G.(1991).

Statistical for business and economics.Max Well Macmillan International editions.Dellen Publishing Co. USA. 1991:272-295. 
Egyptian J. of Nutrition Vol. XXXIV No. 2 (2019)

Mehta, L.K., Balaraman, R., Amin, A.H., Bafna, P.A., and Gulati, O.D. (2003).

Effect of fruits of Moringaoleifera on the lipid profile of normal and hypercholesterolaemic rabbits. J Ethnopharmacol 86: 191-195.

Muruganandan, S., Srinivasan, K., Gupta, S., Gupta, P.K., and Lal, J. (2005).

Effect of mangiferin on hyperglycemia and atherogenicity in streptozotocin diabetic rats. J Ethnopharmacol 97: 497-501.

Nelson, J.A., and Trout, G.H. (1981).

Judging of dairy products, 4th Ed. INC Westport, Academic Press. 345-567.

Page, A. L., Miller, R. H. And Keeney, D. R., (1992).

Methods of soil analysis, part-2 chemical and microbial properties, 2nd edn. Am. Soc. Agronomy and Soil Sci. Soc. Am., Inc., Publs., Madison, Wasconsis, USA.

Pandya, N., Santani, D., and Jain, S. (2006).

Antioxidant activity of ezetimibe in hypercholesterolemic rats. Indian J. Pharmacol ., 38 ( 3 ): 205-206. 


\section{El sayed Hassan Atwaa and Ahdab A. Elmaadawy}

Panwar, H., and Guha, M. (2014).

Effect of processing on nutraceutical properties of garden cress (lepidiumsativumL.) seeds. International Journal of Pharmacy and Pharmaceutical Sciences. $6(7): 315-318$.

Reder, S., and Hartmann, H. (1994).

Diagnostic and pathophysiological aspects of the determination of kidney function in animals. ZentralbIVeterinarmed A.; 41(4):253-67.

Reinhold, J.G. (1953).

Submitted by, to Standard Methods in Clinical Chemistry, Editor Reiner, M., Volume I, Academic Press, New York, 1- 88.280-288.

Sandoval-Castilla, O., Lobato-Calleros, C., AguirreMandujano, E., Vernon-Carter. R.J. (2004).

Microstructure and texture of yogurt as influence by fat replacers. Int Dairy J, 14, 51-159.

Sharma, R.D. (1984).

Hypocholesterolemic activity of fenugreek (T.foemungraecum) an experimental study in rats.Nutr. Rep. Int. 30:221-231. 
Egyptian J. of Nutrition Vol. XXXIV No. 2 (2019)

Škerget, M., Kotnik, P., Hadolin, M., Rižner-Hraš, A., Simonič, M., and Knez, Z. (2005).

Phenols, proanthocyanidins, flavones and flavonols in some plant materials and their antioxidant activities. Food Chem., 89: 191-198.

Tiwari, P. N., and Kulmi, G. S. (2004).

Performance of Chandrasur (Lepidiumsativum) under different levels of nitrogen and phosphorus. J. Med. Arom. Plant. Sci., 26: 479-481.

Zia-Ul-Haq, M., Ahmad, S., Calani , L., Mazzeo ,T., Del Rio ,D., Pellegrini ,N., and De Feo, D.(2012).

Compositional Study and Antioxidant Potential of Ipomoea hederaceaJacq.andLepidiumsativum $\mathrm{L}$. Seeds. Molecules, 17: 10306-10321. 


\title{
El sayed Hassan Atwaa and Ahdab A. Elmaadawy
}

\author{
تأثير اليوجورث منخفض الاهن المدعم بمسحوق بذور حب الرشاد على

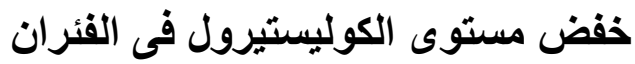 \\ السيد حسن عطوة ا , أهداب عبده المعداوى

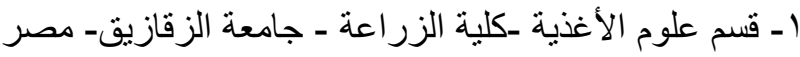

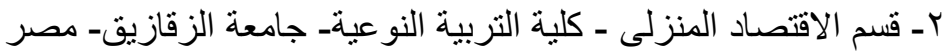

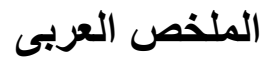

بذور حب الرشاد غنية فى محتواها من الالياف الغذائية والاملاح المعدنية

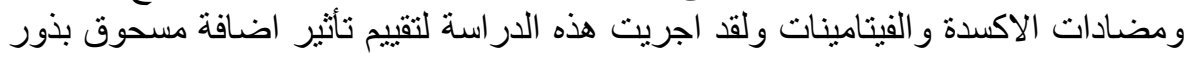

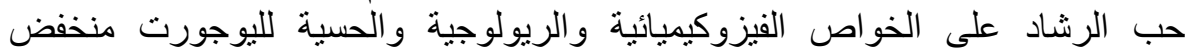

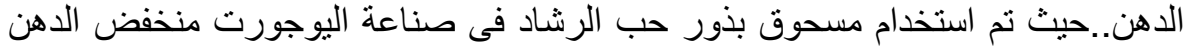

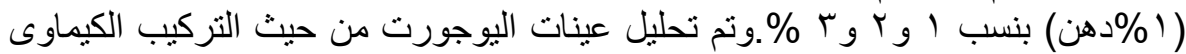

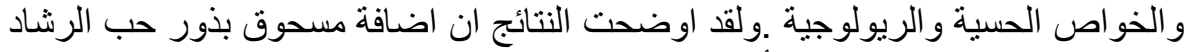

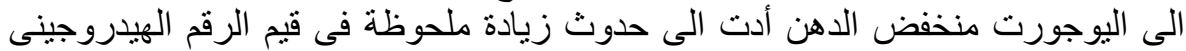

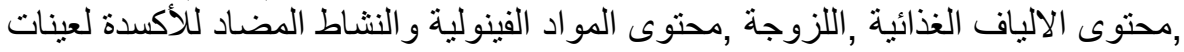

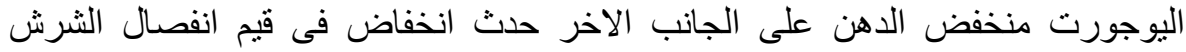

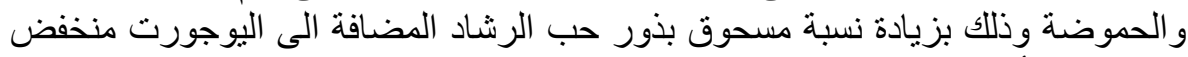

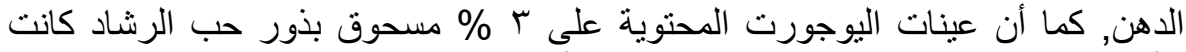

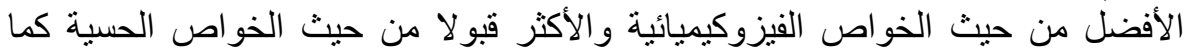

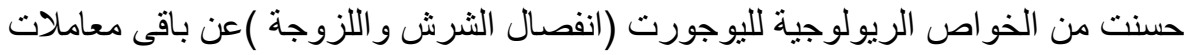

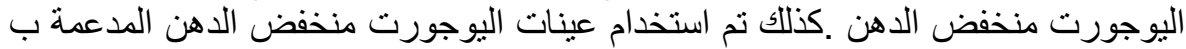

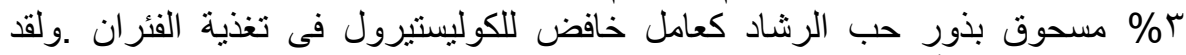

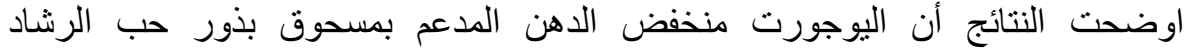

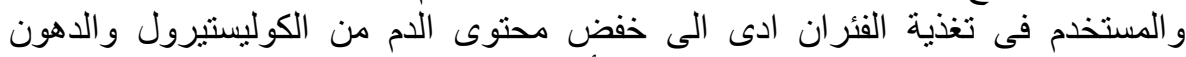

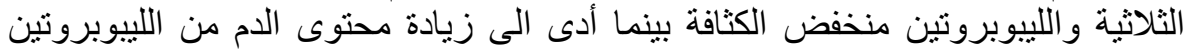

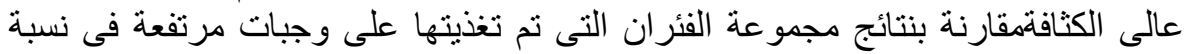

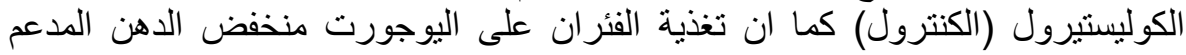

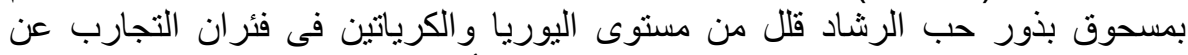

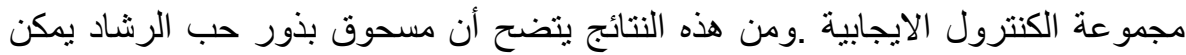

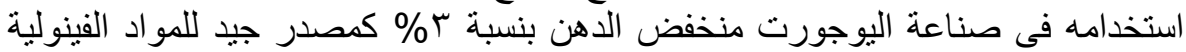

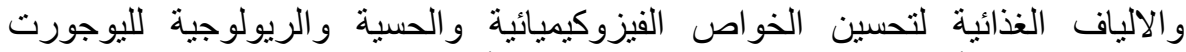

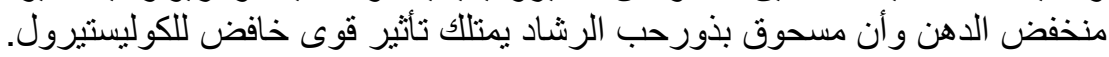

